慶應義塾大学学術情報リポジトリ

Keio Associated Repository of Academic resouces

\begin{tabular}{|c|l|}
\hline Title & $\begin{array}{l}\text { Effects of Immunosuppressive Agents on Magnesium Metabolism Early after Allogeneic } \\
\text { Hematopoietic Stem Cell Transplantation }\end{array}$ \\
\hline Sub Title & 同種造血幹細胞移植後早期のマグネシウム代謝に及ぼす免疫抑制剤の影響 \\
\hline Author & 相佐, 好伸(Aisa, Yoshinobu) \\
\hline Publisher & 慶應医学会 \\
\hline Publication year & 2006 \\
\hline Jtitle & 慶應医学 (Journal of the Keio Medical Society). Vol.83, No.4 (2006. 12),p.8- \\
\hline JaLC DOI & \\
\hline Abstract & \\
\hline Notes & 号外 \\
\hline Genre & Journal Article \\
\hline URL & https://koara.lib.keio.ac.jp/xoonips/modules/xoonips/detail.php?koara_id=AN00069296-2006120 \\
& 2-0008 \\
\hline
\end{tabular}

慶應義塾大学学術情報リポジトリ(KOARA)に掲載されているコンテンッの著作権は、それぞれの著作者、学会または出版社/発行者に帰属し、その権利は著作権法によって 保護されています。引用にあたっては、著作権法を遵守してご利用ください。

The copyrights of content available on the KeiO Associated Repository of Academic resources (KOARA) belong to the respective authors, academic societies, or publishers/issuers, and these rights are protected by the Japanese Copyright Act. When quoting the content, please follow the Japanese copyright act. 


\section{Effects of Immunosuppressive Agents on Magnesium Metabolism Early after Allogeneic Hematopoietic Stem Cell Transplantation

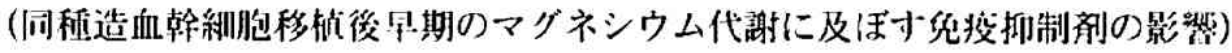

\section{相 佐 好 伸}

\section{内容の要旨}

シクロスホリン (CSA やタクロリムス (FK) リカルシニューリ

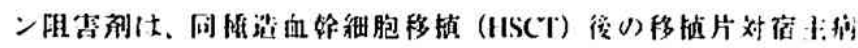

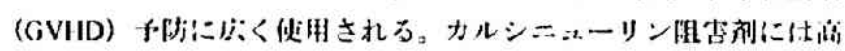

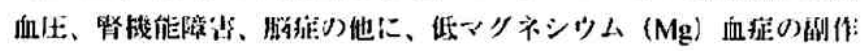

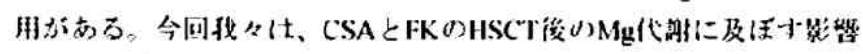

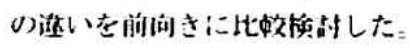

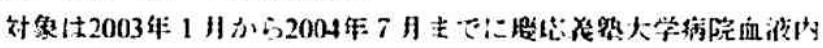

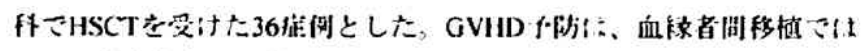

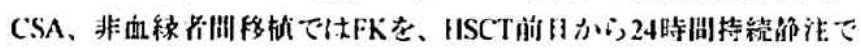

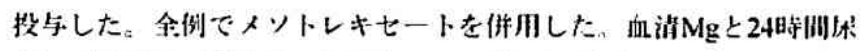

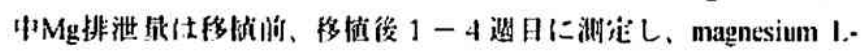

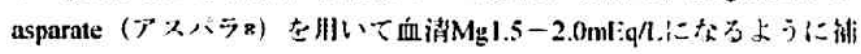

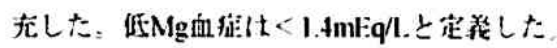

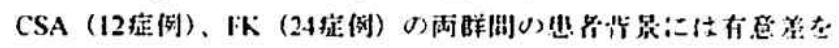

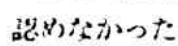

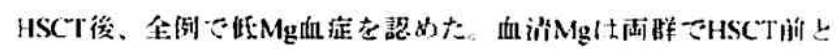

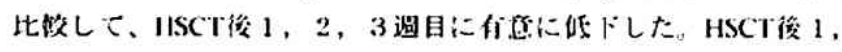

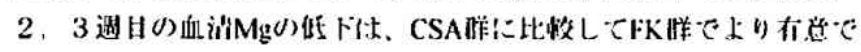

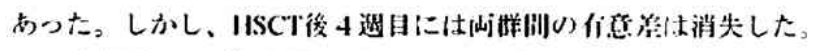

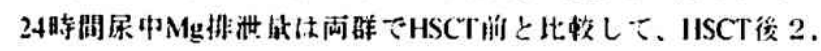

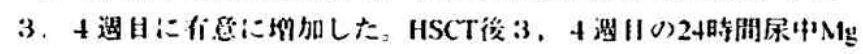

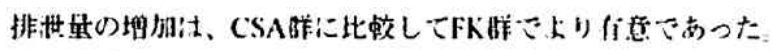

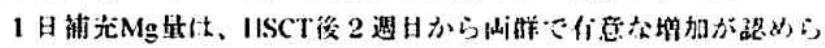

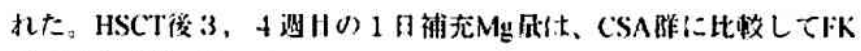
羘て上り有意ですた。

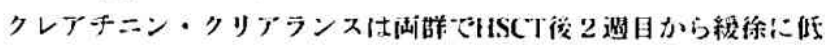

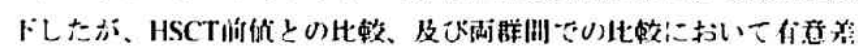

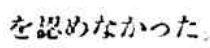

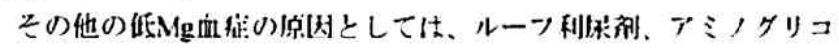

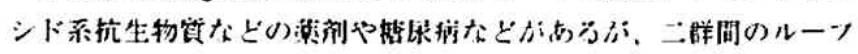

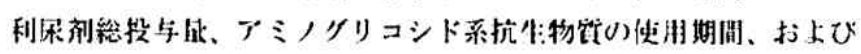

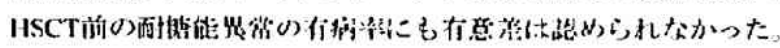

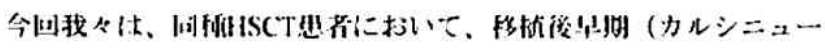

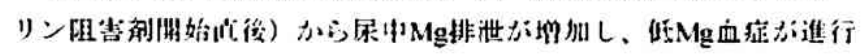

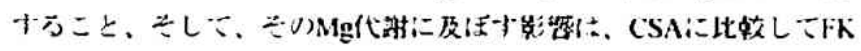

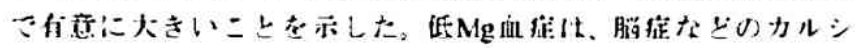

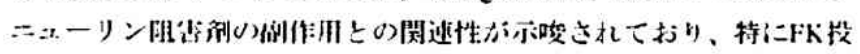

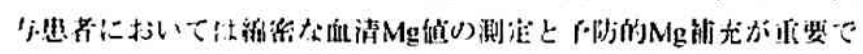
あ゙た上考えられた。

\section{論文蕃查の要旨}

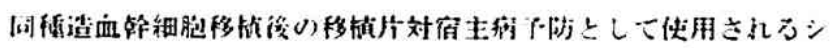

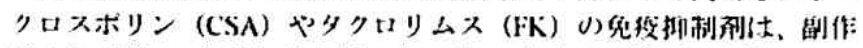

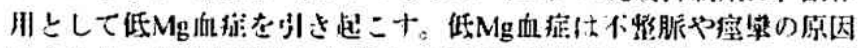

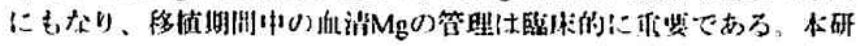

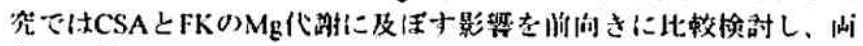

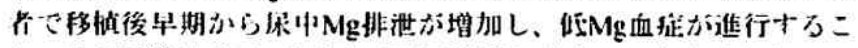
上、そク影缺はCSAに比败してトだ有意に大きいことを示した。

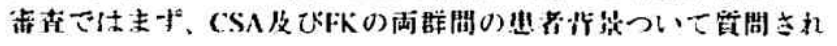

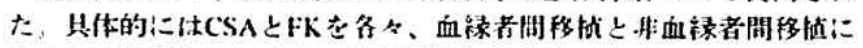

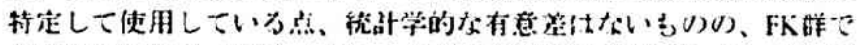

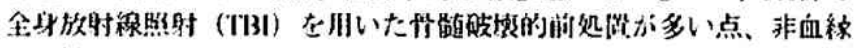

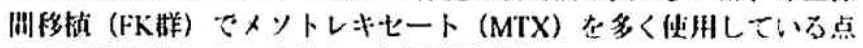

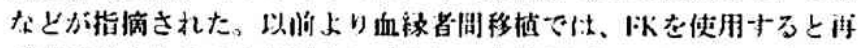

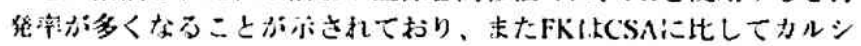

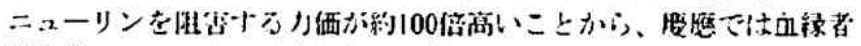

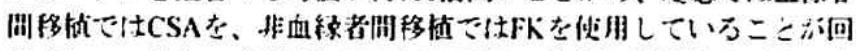

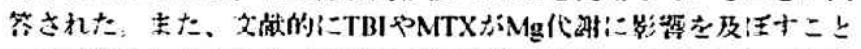

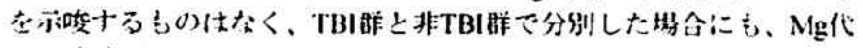

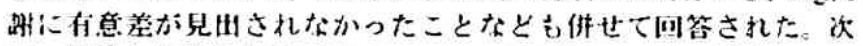

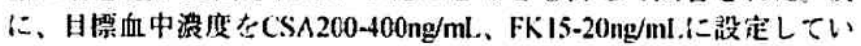

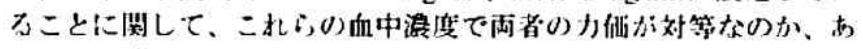

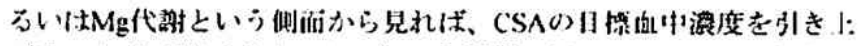
げうことが可乾てはないか、という留閒に対しては、CSAの血中泿

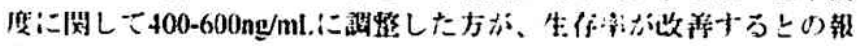

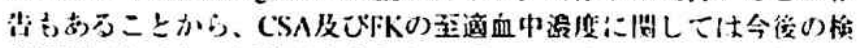

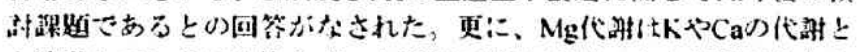

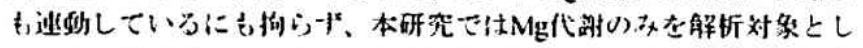

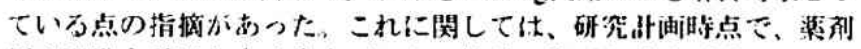

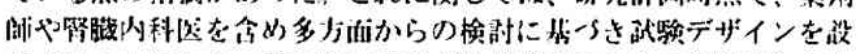

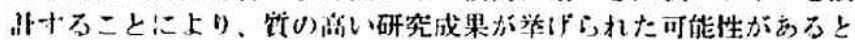

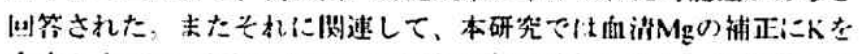

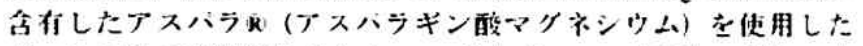

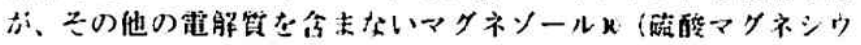

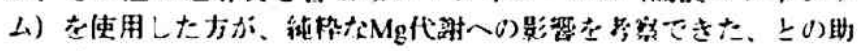
、学营りた。

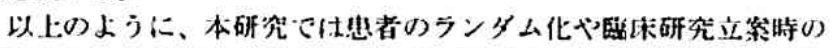

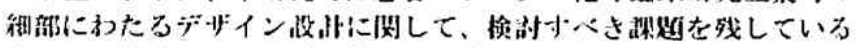

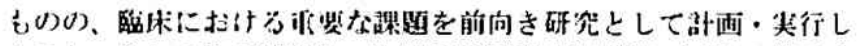

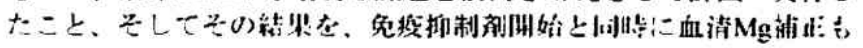

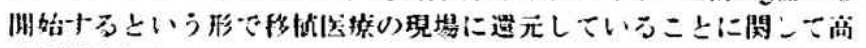
く覀価さ机た

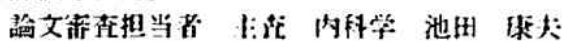

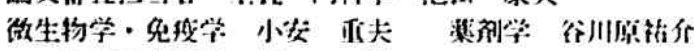

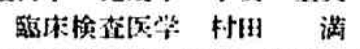

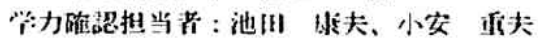

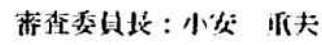

